\title{
Mortality of marine bacteria in response to enrich- ments of the virus size fraction from seawater
}

\author{
Lita M. Proctor ${ }^{1, *}$, Jed A. Fuhrman ${ }^{2}$ \\ ${ }^{1}$ Marine Sciences Research Center, State University of New York at Stony Brook, New York 11794-5000, USA \\ ${ }^{2}$ Department of Biological Sciences, University of Southern California, Los Angeles, California 90089, USA
}

\begin{abstract}
The potential for viral lysis of marine bacteria in seawater enriched with the virus size fraction from seawater was investigated in seawater samples from Long Island Sound, USA, the eastern Pacific Ocean and the Caribbean Sea. Ultrafiltration was used to concentrate material from seawater in the $>0.05 \mu \mathrm{m}$ to $<0.22 \mu \mathrm{m}$ size fraction. Electron microscopy counts of virus-like particles in the high molecular weight concentrate (HMWC) correlated closely to epifluorescence microscopy counts of $<0.22 \mu \mathrm{m}$ DAPI-positive, DNase-resistant particles of the HMWC. Acridine orange direct counts of bacterial abundances significantly declined (often to $1 / 2$ or less of controls) when seawater was incubated with 4- to 16-fold enrichments of HMWC. Microwave treatment of the HMWC before addition to seawater virtually eliminated the declines in bacterial abundance. The combined evidence of the size range of particles, the heat lability of the HMWC and the presence of $<0.22 \mu \mathrm{m}$ DAPI-fluorescent, DNase-resistant particles by epifluorescence microscopy and abundant virus particles by electron microscopy suggests that a dominant bacterial mortality agent in the seawater concentrate was bacteriophage, although we could not rule out an effect of high molecular weight proteins.
\end{abstract}

\section{INTRODUCTIONS}

Little attention has been paid to the mortality of natural bacteria by pathogenesis. Early studies on bacterial survival in estuarine waters and seawater has led to the suggestion that naturally-occurring high molecular weight substances acting as 'antibacterial agents' were responsible for the observed decline of enteric bacteria in seawater (Saz et al. 1963, Massey 1970. Moebus 1972, Anderson et al. 1983). Similarly, other studies have suggested that bacteriophages may be responsible for the decline of enteric bacteria as well as native bacteria in marine waters (Servais et al. 1985, Martinez et al. 1989), although no direct evidence for bacteriophages was presented.

Previously, we reported on electron microscopy examination of marine bacteria and cyanobacteria which demonstrated that virus-caused mortality of marine bacteria and cyanobacteria is a significant mode

\footnotetext{
- Addressee for correspondence; current address: Department of Microbiology and Molecular Genetics, University of California at Los Angeles, Los Angeles, CA 90024-1489, USA
}

of mortality in marine microbial communities (Proctor et al. 1988, Proctor \& Fuhrman 1990, 1991). However, we desired a field technique to demonstrate virus-induced bacterial mortality in situ. To perform field observations of virus-induced bacterial mortality, we believed we needed to 'enhance' any mortality effect in order to carry out the field measurements within a relatively short period of time to avoid containment effects on the microbial community (Ferguson et al. 1984).

There appears to be no satisfactory means of exclusively concentrating native viruses from seawater. Many techniques developed for concentrating viruses from the environment involve elution of viruses from charged surfaces with laborious $\mathrm{pH}$ adjustments and desalting steps (reviewed in Berg 1987) which can inactivate many native viruses (Primrose \& Day 1977. Moebus 1987) and further, contaminate the sample. We adapted ultrafiltration methodology (Belfort et al. 1976) to directly concentrate material in the virus size fraction from seawater $(>0.05 \mu \mathrm{m}$ to $<0.22 \mu \mathrm{m}$ size fraction) to concentrate viruses from seawater without the added elution steps which could cause inactivation. However, we were still concerned that the high molec- 
ular weight concentrate (HMWC) would contain only virus 'ghosts' or viruses devoid of nucleic acid (Earnshaw et al. 1978). By electron microscopic observation, HMWC included high abundances of recognizable free virus particles which appeared to contain nucleic acid, suggesting that these viruses remain whole and potentially active after the concentration step. This suggests that ultrafiltration is an effective method for collecting virus particles from seawater, although it must be borne in mind that large macromolecules and small non-virus particles are concentrated along with the viruses.

Here we report the results of field experiments in which we added HMWC to seawater to observe its effects on the bacterial community. We tracked changes in bacterial abundances in response to the HMWC enrichments with acridine orange direct cell counts by epifluorescence microscopy (Hobbie et al. 1977).

We also tracked free virus abundances by electron microscopy (Proctor \& Fuhrman 1990). However, since electron microscopy is a labor-intensive technique and impossible to carry out on-board ship, we wanted to develop a simpler technique to estimate total virus abundances. We were aware that occasional mention is made of high abundances of $<0.2 \mu \mathrm{m}$ particles in samples prepared for acridine orange direct counts (Newell et al. 1986). In addition, anecdotal accounts of 'blooms' of $<0.2 \mu \mathrm{m}$ particles that stain with acridine orange or DAPI have been made by students in the Fuhrman lab (Long Island Sound) and in other labs (H. Ducklow \& H. Quinby pers. comm., Chesapeake Bay) during routine direct counts of aquatic bacteria. We suspect that many of these particles may be viruses. Previously, DAPI has been utilized to visualize T4 phage by epifluorescence microscopy (Coleman et al. 1981). Recently, Suttle et al. (1990) used this fluorochrome to indicate the presence of presumed viruses in seawater, although they did not examine the same material by electron microscopy. Hara et al. (1991) compared the use of DAPI staining versus negative staining for counting aquatic viruses. In this study, we compared electron microscopy and DAPI epifluorescence microscopy counts of both cultured T3 and T4 phage lysates and of virus-sized particles in the HMWC. In addition, we enumerated changes in the abundances of $<0.22 \mu \mathrm{m}$ DAPI-fluorescent, virus-sized particles to determine whether we could track changes in bacterial abundances with changes in $<0.22 \mu \mathrm{m}$ DAPI-fluorescent particles as a part of the bacterial mortality field experiments.

\section{MATERIALS AND METHODS}

Seawater HMWC preparation. The HMWC was prepared by ultrafiltration (Belfort et al. 1976, Proctor \& Fuhrman 1990) from a total of 5 sites from both nearshore and open ocean seawater (Table 1) by the following protocol (Fig. 1). Only plastic containers were used. The seawater was collected in acid-washed Niskin bottles, and transferred to acid-washed polypropylene $20 \mathrm{l}$ carboys with plastic bulkhead fittings which converted the carboys to pressure vessels (Nalgene Corp.). To remove bacteria and the larger organisms, the seawater was filtered through $142 \mathrm{~mm}$ diameter A/E glass fiber and $0.22 \mu \mathrm{m}$ Durapore filters at low pressure (ca $75 \mathrm{kPa}$ ) through Teflon filtration units (either Millipore Corp. or Micro Filtration Systems Corp.) which were connected in series by high pressure, nontoxic polyvinyl chloride tubing; the filtration units were placed on ice during the prefiltration step. After placed in-line, both prefilters were flushed with several (ca 5 to 10) liters of seawater before the concentration step. The $0.22 \mu \mathrm{m}$ filtrate was collected in acid-washed, collapsible $20 \mathrm{l}$ cubitainers which served as the reservoir during the concentration step. This prefiltered seawater was concentrated in a hollow fiber cartridge (H1P-100, Amicon Corp.; nominal molecular mass cutoff of 100000 or $50 \mathrm{~nm}$ spherical diameter for globular proteins) by using a peristaltic pump, fitted with foodgrade Norprene tubing, to a final volume of 25 to $75 \mathrm{ml}$ in 8 to $16 \mathrm{~h}$ (pressure: ca $75 \mathrm{kPa}$ ). Dead volume in the cartridge was recovered by reversing the pump flow direction and drawing a slight vacuum $(<125 \mathrm{~mm} \mathrm{Hg})$ on the cartridge. Between experiments, the cartridge was cleaned with repeated

Table 1. Locations of bacterial mortality field experiments with date, depth of water sample and water temperature

\begin{tabular}{|c|c|c|c|c|}
\hline Site & Coordinates & Date & $\begin{array}{l}\text { Depth } \\
\text { (m) }\end{array}$ & $\begin{array}{c}\text { Water } \\
\text { temperature }\left({ }^{\circ} \mathrm{C}\right)\end{array}$ \\
\hline \multirow[t]{2}{*}{ Long Island Sound (LIS) } & $40^{\circ} 55^{\prime} \mathrm{N}, 73^{\circ} 09^{\prime} \mathrm{W}$ & June 16,1988 & 1 & 17 \\
\hline & & Aug 28, 1988 & $i$ & 24 \\
\hline Eastern Caribbean Sea (ECS) & $12^{\circ} 35^{\prime} \mathrm{N}, 61^{\circ} 47^{\prime} \mathrm{W}$ & Mar7, 1988 & 100 & 22 \\
\hline Western Caribbean Sea (WCS) & $17^{\circ} 51^{\prime} \mathrm{N}, 79^{\circ} 41^{\prime} \mathrm{W}$ & Nov 7,1988 & 100 & 25 \\
\hline Eastern Pacific Ocean (EPO) & $34^{\circ} 49^{\prime} \mathrm{N}, 124^{\circ} 08^{\circ} \mathrm{W}$ & Apr 21, 1989 & 100 & 13 \\
\hline
\end{tabular}




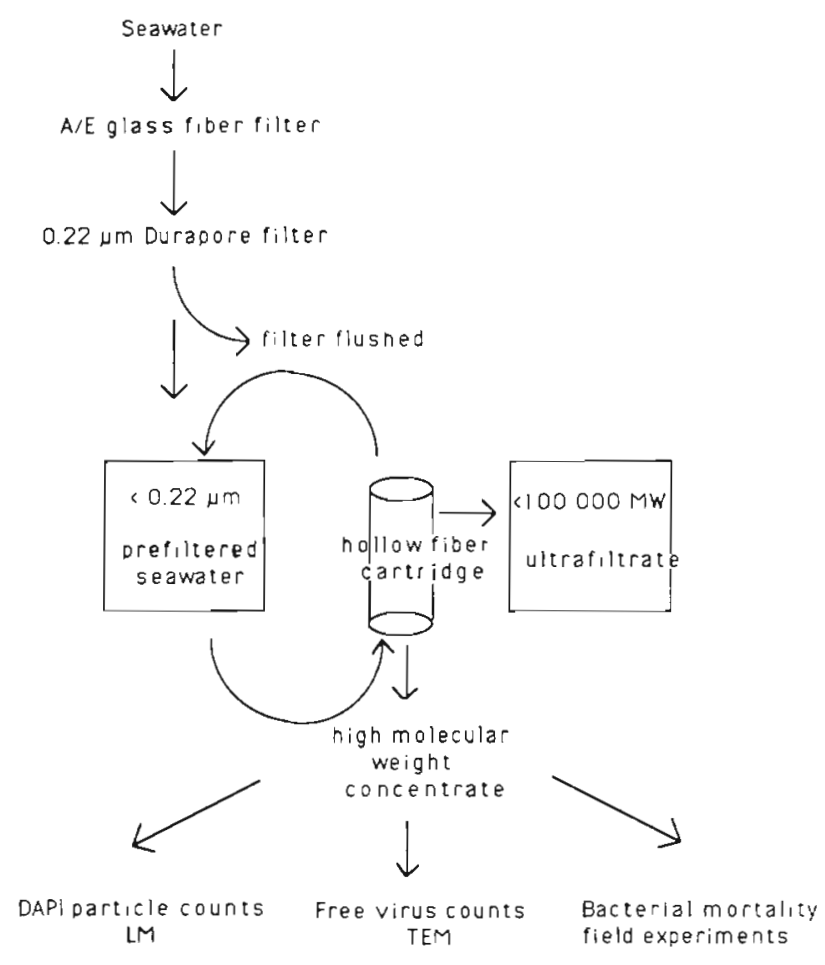

Fig. 1 Protocol for concentrating particles within the $>0.05 \mu \mathrm{m}(100000 \mathrm{MW})$ to $<0.22 \mu \mathrm{m}$ size fraction from seawater by molecular ultrafiltration

$1 \%$ hydrogen peroxide washes; the cartridge was stored in a $5 \%$ hypochlorite solution between sample runs. Typically, between several tens of liters (nearshore sites) to $>100 \mathrm{l}$ (open ocean sites) of seawater were concentrated in this manner.

Electron microscopy of HMWC. The resultant HMWC was subsampled for 3 purposes (Fig. 1). A subsample was fixed with EM grade glutaraldehyde to a final concentration of $0.5 \%$ for electron microscopy counts of free viruses using uranyl sulfate as the negative stain (Proctor \& Fuhrman 1990). In negative stain preparations, virus heads devoid of nucleic acid will strongly stain since the electron-dense stain would penetrate the virus head while viruses containing nucleic acid, although somewhat variable, will typically stain lightly since the nucleic acid in the virus head prevents stain penetration (Earnshaw et al. 1978). We used this criterion to indicate the presence of viruses devoid of nucleic acid and therefore, the percentage of viruses that are potentially inactive in seawater.

Epifluorescence microscopy of HMWC. The combination of DNase treatment and DAPI staining was evaluated as a means of tracking virus-sized particles by epifluorescence microscopy. Even though virussized particles are beyond the theoretical limit of resolution of the light microscope, virus particles with DNA content as small as 4 to $6 \mathrm{~kb}$ can be seen by epi- fluorescence microscopy (A. Coleman, Brown Univ., pers. comm.) because DAPI-stained virus particles appear as pinpoints of blue light against the blackened filter background. It has been suggested that it may be the highly condensed state of viral DNA as compared to bacterial DNA (F A. Eiserling, U.C.L.A., pers, comm.) which allows the viruses to fluoresce particularly brightly. [For comparison purposes, a T4 phagehead with $166 \mathrm{~kb}$ of DNA would contain $343 \mathrm{fg}$ DNA $\mu \mathrm{m}^{-3}$ while a bacterium with $4700 \mathrm{~kb}$ of DNA. (i.e. Escherichia coli) would contain $27.5 \mathrm{fg} \mathrm{DNA} \mu \mathrm{m}^{-3}$ if evenly distributed over the cell (data for calculations taken from Kornberg 1980), indicating that DNA in a T4 phagehead is ca $12 \times$ more condensed than DNA in a bacterial cell.] Samples (100 to $250 \mu \mathrm{l}$ ) were DNasetreated (DNase I Type II, Sigma Chemical Co,; essentially free of proteases and RNase, at $1 \mathrm{mg} \mathrm{ml}^{-1}$ at room temperature for $1 \mathrm{~h}$ ) prior to DAPI-staining to remove dissolved DNA (DeFlaun et al. 1986). Then they were stained with DAPI (final concentration: $1 \mu \mathrm{g} \mathrm{m} \mathrm{m}^{-1}$ ) for $5 \mathrm{~min}$ immediately prior to filtration, mounted in Cargille type A immersion oil and enumerated through an A100PL $100 \times$ objective on an Olympus epifluorescence microscope with ultraviolet excitation and $1250 \times$ magnification. The HMWC was filtered onto either a $0.1 \mu \mathrm{m}$ (March 7, 1988 sampling date) or $0.08 \mu \mathrm{m}$ (all other sampling dates) Irgalan Black-prestained Nuclepore filter. The fluorescence of DAPI-stained material is brighter through an Achromat objective than an SPlan objective (Porter \& Feig 1980).

Field trials testing HMWC enrichments on marine bacteria. A third subsample of the freshly collected HMWC was added to seawater for the bacterial mortality field experiments. Seawater, collected from the same depth as the HMWC and either unfiltered, or prefiltered $(1.0 \mu \mathrm{m}$ Nuclepore), was inoculated with a 4 - to 16-fold enrichment of the HMWC. Enrichment factors were calculated by multiplying the concentration factor of the prepared HMWC by the dilution factor of the HMWC added to a set of samples. Enrichment factors were also checked by calculating the ratios of the number of $<0.22 \mu \mathrm{m}$ DAPI-fluorescent particles in whole seawater to the number of DAPIfluorescent particles in the HMWC before DNase treatment; the actual ratios were generally within 75 to $90 \%$ of predicted ratios based upon the total volumes of seawater processed.

Microwave treatment was selected as a means of inactivating heat-labile viruses (Sanborn et al. 1982) in the HMWC. A 10 to $25 \mathrm{ml}$ subsample of HMWC in a tightly screw-capped, polycarbonate $100 \mathrm{ml}$ flask was microwaved at the highest power output of the microwave oven (typically $>800 \mathrm{~W}$ ) for $3 \mathrm{~min}$ at $30 \mathrm{~s}$ intervals with the sample iced down between microwave 
exposures to prevent boiling. Temperature of the HMWC reached 85 to $90^{\circ} \mathrm{C}$ before placed on ice. Samples were incubated on a reciprocating platform in $1 \mathrm{l}$ acid-washed PVC cubitainers in an illuminated incubator held at the in situ seawater temperature. At sea, samples were incubated in on-deck flowing seawater incubators with appropriate screening to simulate the light intensity at the depth of the sample collection. Triplicate subsamples at time 0 and at the final time point as well as selected timepoints over the course of the experiment were taken for epifluorescence microscopy direct counts of Acridine Orangestained bacteria and $<0.22 \mu \mathrm{m}$ DAPI-fluorescent particles.

Several types of treatment controls were performed in these bacterial mortality field experiments. Controls were performed in which seawater samples were incubated with microwave-treated HMWC. Prefiltered $(1.0 \mu \mathrm{m}$ Nuclepore) seawater served as the grazer-free control against which both prefiltered seawater with HMWC enrichments and prefiltered seawater with microwaved HMWC enrichments were compared. The treatments in which prefiltered seawater received HMWC enrichments served as the treatments with any 'enhanced virus effect'. The treatments of prefiltered seawater with microwaved HMWC were designed to eliminate the effect of any heat-labile viruses and high molecular weight proteins while still retaining the same general composition of the HMWC. Unfiltered, whole seawater combined the effects of both native viruses and bacteriovores and served as a control for the treatments in which whole seawater received virus enrichments in the form of HMWC.

Statistical analysis. For statistical analysis of the treatment effects ( $\mathrm{n}=5$ treatments), the bacterial abundance data from each of the 5 sites was calculated as a percentage change in bacterial abundances from the start of the experiment $(\mathrm{t}=0 \mathrm{~h})$ to the final timepoints ( $\mathrm{t}=18$ to $24 \mathrm{~h}$ ), disregarding the intermediate timepoints. Each of the 5 sites were then handled as a treatment replicate. Since there were negative percentage changes in bacterial abundances in some of the treatments, a square root transformation was carried out on the ratios after the largest negative value $(-44.57 \%)$ was added to all of the data points (Steel \& Torrie 1960, Snedecor \& Cochran 1980). Homogeneity of variances of the transformed data was tested by the Levene's test (test result: $F=$ 1.789 ; $\mathrm{df}=4,18$ ), which is much less sensitive to data with long-tailed distributions than other tests for homogeneity of variances (Snedecor \& Cochran 1980, Neter et al. 1985). Statistical analyses (1-way ANOVA, $\mathrm{p}=0.05$ ) of the transformed data was performed (calculated $F=5.88$; df $=8,14$; SAS 1988). The 3 planned comparisons of (1) filtered seawater and filtered seawater with HMWC, (2) whole seawater and whole seawater with HMWC, and (3) filtered seawater and filtered seawater with microwaved HMWC were tested with orthogonal contrasts (which are particularly applicable for small sample sizes; Steel \& Torrie 1960) at 0.05 (SAS 1988).

A similar transformation and statistical analysis was carried out on the $<0.22 \mu \mathrm{m}$ DAPI-fluorescent particle abundances. A paired $t$-test was also carried out with the counts for the $<0.22 \mu \mathrm{m}$ DAPI-fluorescent particles in the HMWC and the companion negative stain counts of virus-like particles in the HMWC.

\section{RESULTS}

Examining all 5 sites as a whole, HMWC enrichments resulted in either declines in bacterial abundances or a lack of an increase in bacterial abundances as seen in the controls at the end of the experiments (Fig. 2).

The mean percentage change in bacterial abundances in whole seawater was significantly different (calculated $t=2.381 ; \mathrm{df}=8$ ) than the mean percentage change in bacterial abundances in whole seawater with HMWC enrichments (Fig. 2). Over all 5 sites, bacterial abundances in whole seawater alone changed little $(1.2 \pm 7.4 \%)$ whereas bacterial abundances in whole seawater with HMWC enrichments decreased by $24 \pm 13.9 \%$ from initial bacterial abundances. The mean percentage change in bacterial abundances in filtered seawater alone was also significantly different (calculated $t=3.399$; $\mathrm{df}=8$ ) than the mean percentage change in filtered seawater with HMWC enrichments

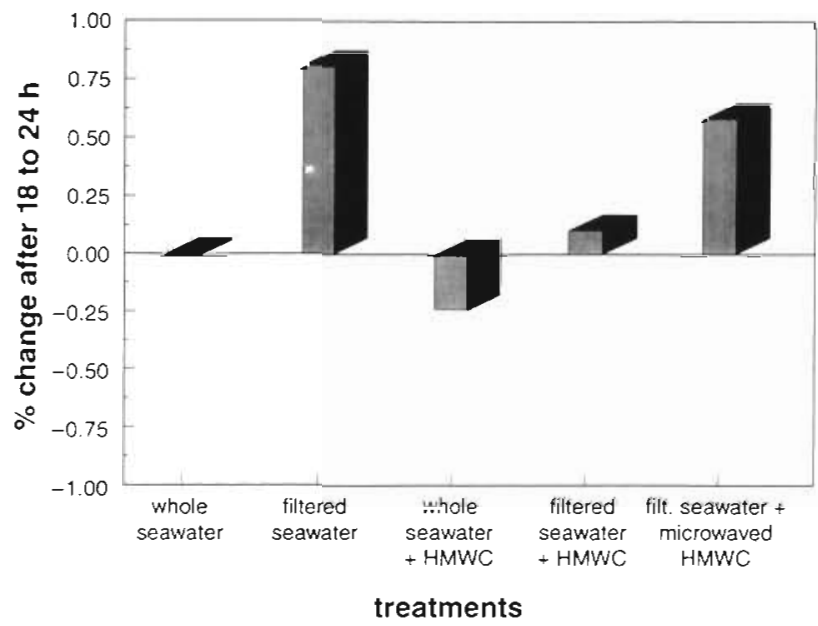

Fig. 2. Percentage change in bacterial abundances at the end of incubations of seawater samples with or without HMWC enrichments. Each bar represents mean percentage change by treatment over 5 sites 
(Fig. 2). Over all 5 sites, bacterial abundances increased by $80.5 \pm 38.1 \%$ in filtered seawater alone whereas bacterial abundances in filtered seawater which received HMWC enrichments increased by only $10.2 \pm 24.7 \%$ from initial bacterial abundances. The effect of HMWC enrichments was eliminated with microwave treatment as the mean percentage change in bacterial abundances in filtered seawater with enrichments of microwaved HMWC was not significantly different (calculated $t=0.99$; df $=8$ ) than the mean percentage change in bacterial abundances with filtered seawater alone (Fig. 2).

Table 2. Initial and final abundances (particles $\mathrm{ml}^{-1}$ ) of $<0.22 \mu \mathrm{m}$ DAPI-fluorescent particles for all treatments for the bacterial mortality field experiments. Whole sw: whole seawater; Filt. sw: filtered seawater; mHMWC: microwaved $\mathrm{HMWC}_{i}$ ND: no data available

\begin{tabular}{|c|c|c|}
\hline Sample & Initial & Final \\
\hline \multicolumn{3}{|l|}{ Near-shore sites } \\
\hline $\begin{array}{l}\text { Long Island Sound } \\
\text { Jun } 16,1988\end{array}$ & $0 \mathrm{~h}$ & $24 \mathrm{~h}$ \\
\hline Whole sw & $7.31 \times 10^{7}$ & $1.33 \times 10^{8}$ \\
\hline Filt. sw & $2.49 \times 10^{8}$ & $4.60 \times 10^{8}$ \\
\hline Whole sw + HMWC & $1.61 \times 10^{9}$ & $3.20 \times 10^{9}$ \\
\hline Filt. sw + HMWC & $7.65 \times 10^{8}$ & $1.45 \times 10^{9}$ \\
\hline Filt. $s w+m H M W C$ & $3.76 \times 10^{8}$ & ND \\
\hline $\begin{array}{l}\text { Long Island Sound } \\
\text { Aug } 28,1988\end{array}$ & $0 \mathrm{~h}$ & $24 \mathrm{~h}$ \\
\hline Whole sw & $7.09 \times 10^{8}$ & $9.88 \times 10^{8}$ \\
\hline Filt. sw & $3.65 \times 10^{8}$ & $7.38 \times 10^{8}$ \\
\hline Whole sw + HMWC & $2.23 \times 10^{9}$ & $4.06 \times 10^{9}$ \\
\hline Filt. sw + HMWC & $9.11 \times 10^{8}$ & $1.32 \times 10^{9}$ \\
\hline Filt. $\mathrm{sW}+\mathrm{mHMWC}$ & $6.01 \times 10^{8}$ & $5.77 \times 10^{8}$ \\
\hline \multicolumn{3}{|l|}{ Open-ocean sites } \\
\hline $\begin{array}{l}\text { Eastern Caribbean Sea } \\
\text { Mar 7, } 1988\end{array}$ & $0 \mathrm{~h}$ & $21 \mathrm{~h}$ \\
\hline Whole sw & $3.77 \times 10^{6}$ & $4.89 \times 10^{6}$ \\
\hline Filt. sw & $2.78 \times 10^{6}$ & $3.09 \times 10^{6}$ \\
\hline Whole sw + HMWC & $1.17 \times 10^{7}$ & $2.47 \times 10^{7}$ \\
\hline Filt. sw + HMWC & $1.21 \times 10^{7}$ & $2.01 \times 10^{7}$ \\
\hline $\begin{array}{l}\text { Western Caribbean Sea } \\
\text { Nov } 7,1988\end{array}$ & $\mathrm{Oh}$ & $21 \mathrm{~h}$ \\
\hline Whole sw & $6.01 \times 10^{6}$ & $1.11 \times 10^{7}$ \\
\hline Filt. sw & $3.98 \times 10^{6}$ & $3.99 \times 10^{6}$ \\
\hline Whole sw + HMWC & $5.11 \times 10^{7}$ & $9.89 \times 10^{7}$ \\
\hline Filt. sw + HMWC & $3.99 \times 10^{7}$ & $6.11 \times 10^{7}$ \\
\hline Filt. sw + mHMWC & $3.09 \times 10^{6}$ & $3.12 \times 10^{6}$ \\
\hline $\begin{array}{l}\text { Eastern Pacific Ocean } \\
\text { Apr 21, } 1989\end{array}$ & $0 \mathrm{~h}$ & $18 \mathrm{~h}$ \\
\hline Whole sw & $2.56 \times 10^{6}$ & $4.07 \times 10^{6}$ \\
\hline Filt. sw & $9.08 \times 10^{5}$ & $9.10 \times 10^{5}$ \\
\hline Whole sw + HMWC & $5.01 \times 10^{6}$ & $4.93 \times 10^{6}$ \\
\hline Filt. sw + HMWC & $4.15 \times 10^{6}$ & $4.34 \times 10^{6}$ \\
\hline Filt, sw + mHMWC & $2.01 \times 10^{5}$ & ND \\
\hline
\end{tabular}

Overall, $<0.22 \mu \mathrm{m}$ DAPI-fluorescent particles appeared to increase the most in whole seawater with HMWC enrichment ( $76 \pm 46 \%)$ and effectively did not change in filtered seawater with microwaved HMWC enrichments $(2 \pm 3 \%$ ) over the course of the experiments (Table 2). However, there were no significant treatment differences (calculated $F=1.11$; df $=8,14$; SAS 1988) between < $0.22 \mu \mathrm{m}$ DAPI-fluorescent particle abundances and therefore, differences in specific pairs of treatment means were not tested.

Although treatment effects were statistically compared by treating all 5 sites as replicates, closer examination of the treatment effects at each site revealed trends over the course of each experiment that were not always replicated at each site. For example, 5-fold enrichments of HMWC in seawater from Long Island Sound collected on June 16, 1988, did not appear to affect bacterial abundances in whole seawater but did appear to affect bacterial abundances in filtered seawater (Fig. 3). However, with the exception of filtered seawater with microwaved HMWC, $<0.22 \mu \mathrm{m}$ DAPIfluorescent particles increased ca 2 -fold from initial abundances in all of the samples (Table 2).

Effects of the HMWC enrichments were more dramatic in experiments conducted near the end of the stratified period (August 28, 1988) in Long Island Sound (Table 1), when 'blooms' of $<0.22 \mu \mathrm{m}$, acridine orange-fluorescent and DAPI-fluorescent particles were often observed (pers. obs.). After 6 h, bacterial abundances in filtered seawater with a 5-fold HMWC enrichment decreased to $47 \%$ of the bacterial abundances in filtered seawater alone (Fig. 4). Bacterial abundances in the HMWC-enriched filtered seawater remained low throughout the experiment and were $39 \%$ of the bacterial abundances in the filtered seawater control at the end of the experiment (Fig. 4). The $<0.22 \mu \mathrm{m}$ DAPI-fluorescent particles did not exhibit particular trends related to the treatments (Table 2).

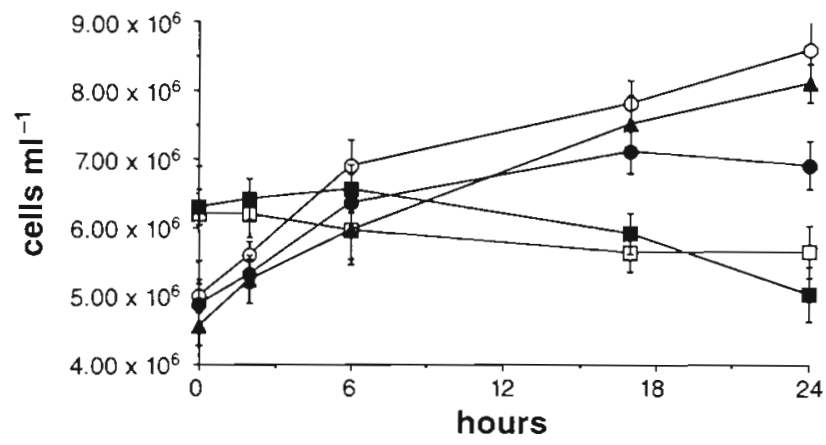

Fig. 3. Bacterial abundances (mean $\pm \mathrm{SD}$ ) in response to 5 -fold enrichments of HMWC, Long Island Sound, $1 \mathrm{~m}$ depth, June 16, 1988. (ㅁ) whole seawater; ( $\square$ ) whole seawater with HMWC; (O) filtered seawater; (-) filtered seawater with HMWC; (A) filtered seawater with microwaved HMWC 


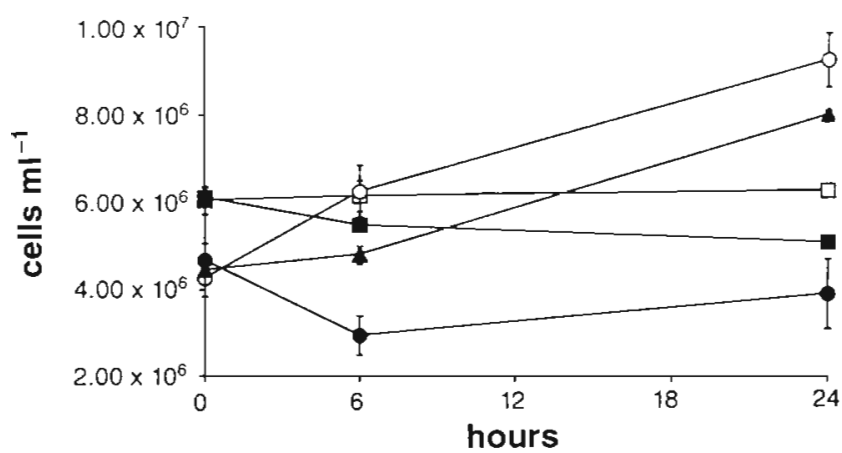

Fig. 4. Bacterial abundances (mean $\pm \mathrm{SD}$ ) in response to 5 -fold enrichments of HMWC, Long Island Sound, $1 \mathrm{~m}$ depth, August 28, 1988. Symbols as in Fig. 3

The mortality experiments in open ocean sites were all conducted with samples from those depths where the highest bacterial abundances were often noted (typically $100 \mathrm{~m}$; pers. obs.).

With Eastern Caribbean seawater, bacterial abundances in filtered seawater with a 4 -fold HMWC enrichment did not change from initial abundances and after $21 \mathrm{~h}$ were $56 \%$ of the bacterial abundances in filtered seawater alone (Fig. 5). The $<0.22 \mu \mathrm{m}$ DAPIfluorescent particles increased ca 1.5- to 2-fold in both of the samples which received the HMWC enrichments (Table 2).

An early and persistent effect was observed in 10fold HMWC enrichments with Western Caribbean seawater (Fig. 6). Within $6 \mathrm{~h}$, bacterial abundances in the filtered seawater with HMWC enrichments decreased to $62 \%$ of the bacterial abundances in filtered seawater alone and continued decreasing to $52 \%$ of bacterial abundances in the filtered seawater control at the end of the experiment (Fig. 6) The $<0.22 \mu \mathrm{m}$ DAPI-fluorescent particles increased ca 1.5 - to 2 -fold over initial abundances in filtered seawater with HMWC enrichments and in whole seawater with or without HMWC enrichments (Table 2).

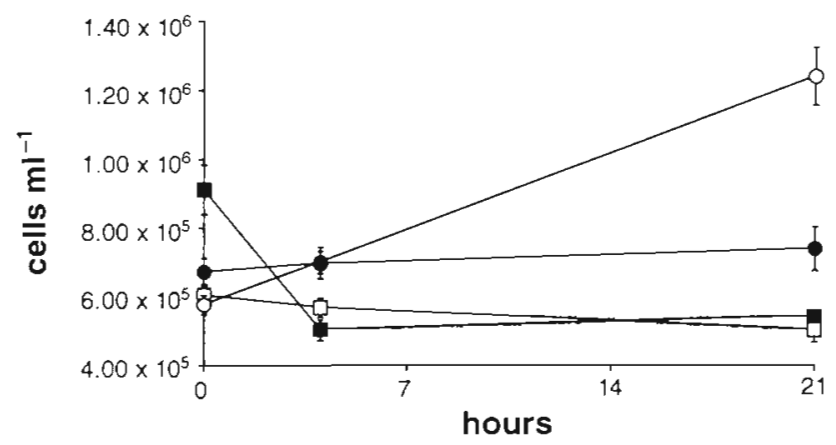

Fig. 5. Bacterial abundances (mean $\pm \mathrm{SD}$ ) in response to 4 -fold enrichments of HMWC, Eastern Caribbean Sea, $100 \mathrm{~m}$ depth, March 7, 1988. Symbols as in Fig. 3

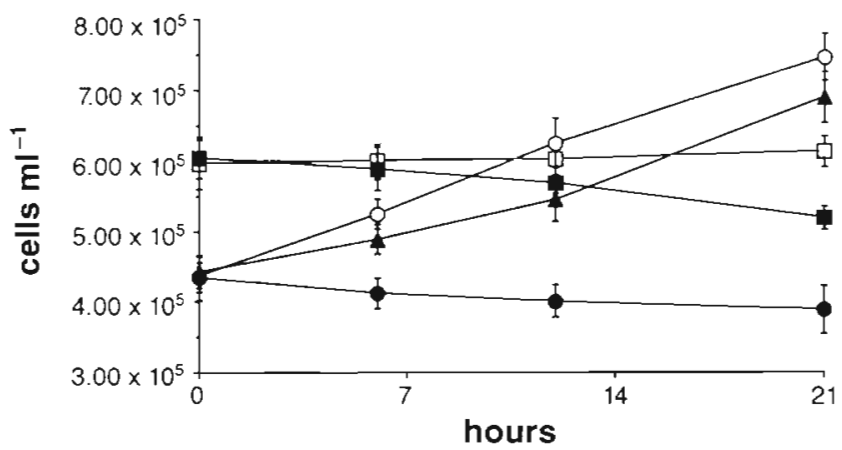

Fig. 6. Bacterial abundances (mean $\pm \mathrm{SD}$ ) in response to 10 . fold enrichments of HMWC, $100 \mathrm{~m}$ depth, Western Caribbean Sea, November 7, 1988. Symbols as in Fig. 3

Bacterial abundances in an HMWC enrichment experiment conducted in the oligotrophic Eastern Pacific in April 1989 demonstrated a less dramatic response than similar experiments from the other field sites. For example, after $10 \mathrm{~h}$, bacterial abundances in 16 -fold HMWC enrichments were $83 \%$ of the bacterial abundances in filtered seawater alone (Fig. 7). No particular trends related to treatment were observed in the $<0.22 \mu \mathrm{m}$ DAPI-fluorescent particle abundances (Table 2). In this series of experiments, the bacterial cells exhibited wide variability in size and morphology between 10 and $18 \mathrm{~h}$ after the experiments began; this resulted in increased variability between replicate acridine orange direct counts which masked any treatment effects (Fig. 7).

Ancillary experiments were conducted to compare the DAPI-fluorescent, DNase-resistant particle counts obtained by epifluorescence microscopy to the free virus counts obtained by transmission electron microscopy from both cultured phage lysate and from HMWC (Fig. 8). Typical variability for replicate counts $(\mathrm{n}=3)$ of $<0.22 \mu \mathrm{m}$ DAPI-fluorescent particles was $6.1 \%$ while replicate EM counts of negative stain preparations of virus-like particles varied by $8.6 \%$. There were no significant differences between the

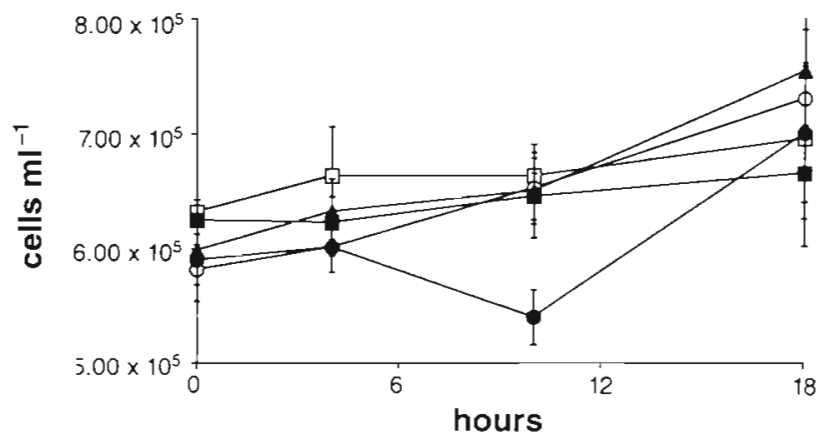

Fig. 7 Bacterial abundances (mean $\pm \mathrm{SD}$ ) in response to $16-$ fold enrichments of HMWC, $100 \mathrm{~m}$ depth, Eastern Pacific Ocean, April 21, 1989. Symbols as in Fig. 3 


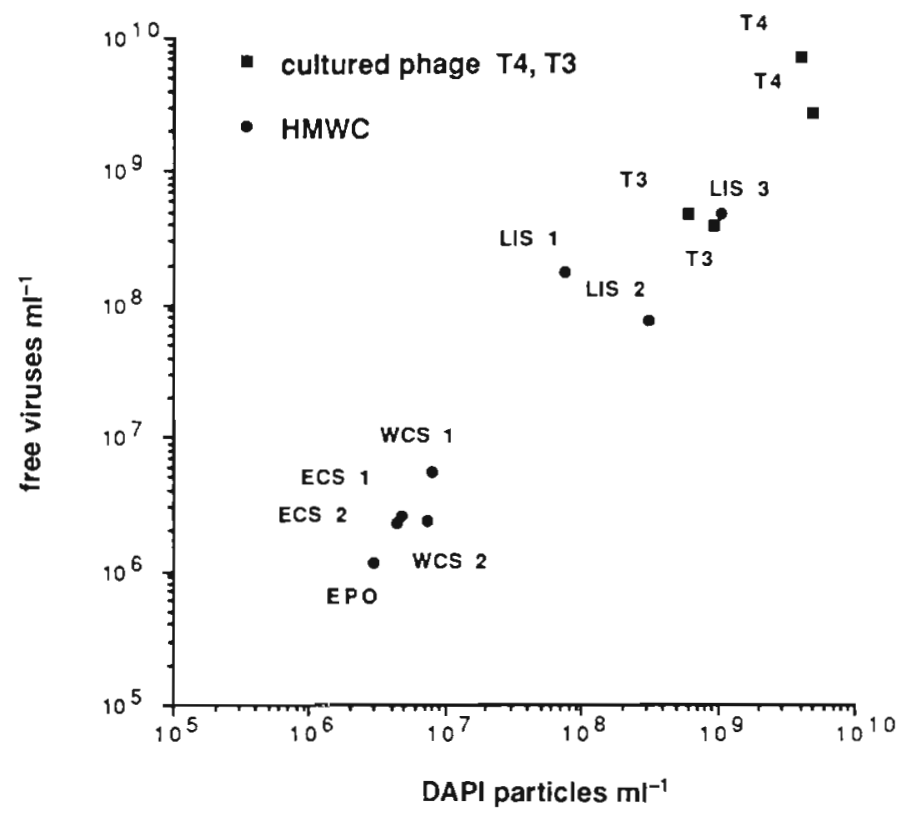

Fig. 8. Counts of $<0.22 \mu \mathrm{m}$ DAPI-fluorescent, DNase-resistant particles and free viruses in cultured phage lysate (T3, T4) and in HMWC from Long Island Sound (LIS), the Caribbean Sea [Eastern (ECS) and Western (WCS)] and the Eastern Pacific Ocean (EPO)

counts of $<0.22 \mu \mathrm{m}$. DAPI-fluorescent particles and virus-like particles in either the cultured phage lysate (calculated $t=0.78$; $\mathrm{df}=7$ ) or the HMWC (calculated $t=1.991 ; \mathrm{df}=23$ ).

An estimate was made of the percentage of potentially-inactive viruses present in the cultured phage lysate and in the HMWC. Based upon electron microscopic evidence that dark-staining virus heads suggest a lack of nucleic acid within the virus particles, a range of 1 to $11 \%$ of both cultured phage lysates appeared to be potentially inactive. In the seawater concentrates, a range of 13 to $48 \%$ of the viruses in the HMWC from all sites appeared to be potentially inactive.

\section{DISCUSSION}

In this study, a mortality agent in the HMWC either directly killed bacteria or inhibited bacterial growth that would have otherwise occurred. Our studies suggest that the dominant mortality agent in the HMWC was viruses, although we could not completely rule out other high molecular weight substances that may be in the concentrated material.

Many aquatic bacteria are known to produce lysozymes, bacteriocins and other bacteriocidal agents (Moebus 1972, McCambridge \& McMeekin 1980). Some early studies examined the bacteriocidal activity of seawater on bacteria (Carlucci et al. 1961, Sieburth
\& Pratt 1962, Saz et al. 1963, Moebus 1972) without identifying the mortality agent. It is highly plausible that macromolecules which are lethal to the native bacteria are present in seawater. Heat treatment removed the bacteriocidal activity in some of the early experiments on bacterial mortality (Carlucci et al. 1961, Saz et al. 1963, Moebus 1972) while in others it has been observed that some bacteriocidal macromolecules are heat-stable (Prescott \& Li 1960). However, since heat treatment would also inactivate viruses, this treatment alone would not be characteristic of a particular mortality agent.

A combination of factors led us to conclude that the mortality agent in our experiments was likely viruses. The concentrate which resulted in bacterial mortality in our studies was collected from the virus size fraction in seawater and contained, by light microscopy, abundant DAPI-fluorescent, DNase-resistant virus-sized particles. These $<0.22 \mu \mathrm{m}$ particles increased in number over time in our incubated seawater samples. In addition, most known lysozymes and bacteriocins are smaller than the $100000 \mathrm{MW}$ cutoff of our uitrafiltration cartridge (Kornberg 1980). Electron microscopy also showed the concentrate contained recognizable virus-like particles.

We recognized that plaque assays would not serve as a complete evaluation of the presence of active viruses in the HMWC since plaque assays would only tell us about a few of the phage-susceptible bacteria in the community. For example, Ewert \& Paynter (1980) found that in sewage the total number of phage estimated by plaque assays averaged only $4 \%$ of the total number of virus-like particles observable by electron microscopy. We examined potential virus infectivity in the concentrate by evaluating by electron microscopy whether the virus heads were replete or devoid of nucleic acid (Earnshaw et al. 1978). Electron microscopic examination of these concentrates indicated that a relatively small percentage of the virus heads were devoid of nucleic acid. The concentrate contained a wide variety of these potentially active viruslike particles, dominated by tailed phage morphotypes (ICTV families Myoviridae, Siphoviridae; Proctor et al. 1988, Proctor \& Fuhrman 1990). Interestingly, Hara et al. (1991) noted that most of the aquatic virus-like particles they observed were particles with either short tails or no tail (i.e. ICTV families Podoviridae or Microviridae).

We took several factors into account in the enumeration of virus-sized particles by epifluorescence microscopy. We removed the potential interference of dissolved DNA by routine DNase treatment of our concentrate since dissolved DNA can be found at high concentrations in aquatic systems (Paul et al. 1987, Karl \& Bailiff 1989). Although we did not measure the 
concentrations of dissolved DNA in our samples, we recognized that dissolved DNA would be concentrated along with the other material in our high molecular weight concentrate. We found, in particular in our nearshore samples, that DNase treatment removed the blue background fluorescence which made counting of the smallest DAPI-fluorescent particles difficult for the microscopist. However, we found that a DNAse stock essentially free of proteases was critical since treatment with an inferior grade of DNAse resulted in degraded virus particles as evidenced in negative stain preparations of treated samples.

We utilized polycarbonate filters (Nuclepore) with $0.08 \mu \mathrm{m}$ pores to collect DAPI-stained particles even though virus particles smaller than $80 \mathrm{~nm}$ are present in seawater (Bergh et al. 1989). We found that viruses smaller than $80 \mathrm{~nm}$ were routinely trapped on the $0.08 \mu \mathrm{m}$ Nuclepore filters, since we did not find any viruses in the filtrate when examined by electron microscopy. We presume this is because the high surface area to pore size ratio of Nuclepore filters traps particles smaller than $0.08 \mu \mathrm{m}$; however, we realize that some viruses probably passed through and broke up into unrecognizable particles. The often high loss of $<0.22 \mu \mathrm{m}$ DAPI-fluorescent particles (ca 30 to $60 \%$ ) in the $1.0 \mu \mathrm{m}$ Nuclepore prefiltration step may have also been due to entrapment of these particles on the Nuclepore filter surface. We suspect that such losses were not as important in our large volume HMWC preparations, as indicated in experiments where $86 \%$ of a T4 phage lysate, seeded in seawater, was recovered (Proctor \& Fuhrman 1990).

It is possible that there are many kinds of DNA and RNA viruses in seawater, although by DAPI epifluorescence microscopy, we specifically enumerated $<0.22 \mu \mathrm{m}$ double-stranded DNA particles. An RNAspecific stain, such as pyronin $\mathrm{Y}$ which has been used with fluorescence flow cytometry (Shapiro 1981, Crissman et al. 1985), may be useful for visualizing RNA viruses. In addition, 2 newly-introduced fluorochromes which have been reported to be highly specific for DNA and RNA, Ethidium Homodimer (Mordy \& Carlson 1991) and Thiazole Orange (Berdalet \& Dortch 1991), may be suitable for visualizing DNA and RNA viruses in seawater.

The seawater was concentrated 200 to 4000 times, depending on the volumes handled, and the concentrate contained a range of ca $10^{11}$ to $10^{14}<0.22 \mu \mathrm{m}$ DAPI-fluorescent particles in a typical $25 \mathrm{ml} \mathrm{HMWC}$. DAPI-stained aliquots of the concentrate enumerated by epifluorescence microscopy were not always similar to the electron microscopy counts. In nearshore environments, we sometimes observed blueautofluorescent particles (unstained preparations) within the same size range as the DAPI-fluorescent particles although these particles typically represented less than $10 \%$ of the DAPI-fluorescent particle abundances. Since we rarely observed bacteria in companion samples of the concentrates examined by electron microscopy, we had confidence we were not counting ultrasmall bacteria. On the other hand, we cannot eliminate the possibility that DNA adsorbed to particles in samples from our nearshore experiments escaped nuclease activity since studies have shown that clay-bound DNA in particular is resistant to DNase attack (Greaves \& Wilson 1969, Lorenz et al. 1981). Alternatively, some marine viruses may stain with DAPI yet exhibit unexpected morphologies which may make them unrecognizable by TEM. Interestingly, Hara et al. (1991) also noted that their ratios of DAPI-positive particles to electron microscopy counts of virus-like particles were frequently greater than 1.0 , further suggesting that non-viral but DAPI-stainable particles may occur in aquatic systems.

In general in all of the experiments, abundances of $<0.22 \mu \mathrm{m}$ DAPI-fluorescent particles increased the most in whole seawater with HMWC enrichments. It is quite possible that HMWC enrichments may have resulted in not only bacterial lysis but also virus infection and lysis of some larger eukaryotes, releasing abundant virus particles (Suttle et al. 1990, Proctor \& Fuhrman 1991). Grazer activity may result in lysis products or excreta which could conceivably be DAPIstaining but non-virus in origin. In addition, confinement of seawater as well as HMWC enrichment may have induced cell lysis by autolysis or prophage induction (Børsheim et al. 1990) resulting in the production of viruses.

We often observed a gradual increase in the $<0.22 \mu \mathrm{m}$ DAPI-fluorescent particles in our controls of filtered and whole seawater which did not receive HMWC. Whether the increase in DAPI-fluorescent particles was due to induction of prophage, bacteriovore excreta or other release mechanisms, the fact that we did not observe concommitant declines in the bacterial abundances in the filtered seawater control suggests that bacterial growth balanced or exceeded the cumulative loss rates of the bacteria from all causes.

The $<0.22 \mu \mathrm{m}$ DAPI-fluorescent particles typically did not increase more than 1.5- to 2-fold above initial concentrations. We can only speculate about the possible reasons why we did not see larger increases in the number of DAPI-fluorescent particles in the treatments which exhibited dramatic declines in bacterial abundances. It is possible that we may have masked our ability to observe a release of virus particles from lysed cells simply because with the HMWC enrichments, we increased the 'signal to noise' ratio of any newly synthesized viruses to the 'added' viruses. 
Because we added between a 4- and 16-fold enrichment of DAPI-fluorescent particles, it would likely require a very large proliferation of virus particles to be able to see these over the relatively high abundance of 'added' viruses

Our inability to detect a greater increase in $<0.22 \mu \mathrm{m}$ DAPI-fluorescent particles may have also been because the burst size, or number of phage particles released per lysed cell, was small. Marine bacteria are small (average biovolume $0.05 \mu \mathrm{m}^{3}$; Lee \& Fuhrman 1987) and may produce fewer total phage per infection cycle than cultured bacterial isolates grown in rich media. For example, we noted that in thin sections of phage-infected marine bacteria (Proctor \& Fuhrman 1990), there were 3 to 100 mature phage per cell section with the frequency distribution skewed towards the lower numbers of phage per cell section, suggesting that burst sizes are relatively small for native bacteria. Also, there is some evidence which suggests that burst size is small for slowergrowing bacteria (Hayes 1976, Saye et al. 1987). Since we were tracking the effect of the virus size fraction on bacterial communities with widely different growth rates and physiological states, we could not expect to see an immediate and large proliferation of viruses. Of course, it is also likely that whatever processes control virus abundance in the sea were also active in our experiments, and this would limit any increases (see below).

The microwave treatment of the concentrate as a control was performed principally because we wanted to heat-inactivate the viruses. Microwave irradiation crosslinks proteins, much in the way a fixative can crosslink proteins (Login 1978) and it is an effective means of inactivating without introducing toxic effects of its own; microwave sterilization has been used safely in critical tissue culture work without side effects (Sanborn et al. 1982). To irradiate our HMWC, we adopted the length of microwave irradiation used by Sanborn et al. (1982) to inactivate T4 phage. Although some plastics (i.e. polycarbonate, polyallomer) are considered marginal for microwaving because they appear to absorb the heat generated during microwaving, in general, 'all plastics allow transmission of microwaves' (1991 Nalgene Catalog).

Although enriching seawater with the virus size fraction is a useful approach for investigating the potential for bacterial mortality, interpretation in terms of natural mortality rates is not straightforward. It is clear in our field experiments that we were not witnessing a uniform effect of HMWC enrichments on the bacterial community since at 2 sites. HMWC enrichments resulted in an early and persistent effect on bacterial abundances (ECS, March 7, 1988; LIS, August 28, 1988) whereas a similar HMWC enrichment at another site (LIS, June 16, 1988) did not appear to immediately affect bacterial abundances.

The dynamics of virus replication in vivo and in vitro are complex and depend on the genetic and ecological factors that govern virus/host interactions. Some of the factors which should be considered can include (but are not limited to): (1) virus adsorption onto surfaces, (2) host death without virus production, (3) the induction frequency of temperate (nonlytic) to lytic forms at the time of sampling and (4) non-viral modes of bacterial mortality. Each of these factors will be briefly discussed.

Viruses readily adsorb to and desorb from surfaces in the natural environment (Bitton \& Mitchell 1974). Clays (Kapuscinski \& Mitchell 1980), colloidal and particulate organic matter (Berg 1973, Proctor \& Fuhrman 1991) and even nonsusceptible hosts (Moebus 1983) can serve as surfaces for virus adsorption and prolong virus survival. An immediate practical consequence of this characteristic is that in carboys, free viruses may adsorb to the inner walls of the vessel, possibly irreversibly. This large new surface could remove a significant proportion of the virus population from interactions with available hosts and thus affect the type of results obtained. In addition, filtration of small volumes of seawater can remove large numbers of viruses on the filter surface, as we sometimes observed with some of our $1.0 \mu \mathrm{m}$ Nuclepore prefiltered seawater samples. Although we selected plastic carboys because glass is known to be an efficient scavenger of proteins, we likely did not completely eliminate the surface effect.

A bacterium requires only 1 lytic phage to successfully attack and inject nucleic acid to result in virus replication and death of that cell (Hayes 1976). If a bacterium is attacked by numerous phage, then a phenomenon known as 'lysis from without' occurs in which the numerous attacking phage weaken the bacterial cell wall to the point where lysis occurs without virus production (Delbrück 1940). If we added too large a number of viruses to our samples, then we may have mimicked 'lysis from without' by causing immediate cell lysis without virus production. There is some precedent for this suggestion. In some marine phage/ host systems, Moebus (1983) has found that at high ratios of phage to host, there is frequent host inhibition and/or death without phage production. Other studies of specific phage/host systems have noted phenomena similar to 'lysis from without' (e.g. Fields 1969, Maiti 1978) which suggests that this may be more common than originally thought. This may have been what we observed in those field experiments with higher enrichments of HMWC since, unlike we anticipated, we did not observe greater bacterial mortality and increasing number of virus particles with greater HMWC enrichments. 
Although it has been suggested that the majority of bacteriophage are temperate (Stewart \& Levins 1984), it is likely that the percentages and induction rates in nature would vary, For example, Børsheim et al. (1990) observed a rapid proliferation of viruses followed by a 2 -fold decline in bacterial abundances, and interpreted this to mean that prophages were induced from the temperate form from many of the bacteria and subsequently lysed other bacteria in the community. Saye et al. (1990) compared long term incubations of lysogenic bacteria in microcosms and in lakes. In microcosms, phage abundances remained constant after an initial proliferation. However, in the companion lake in situ incubations, phage abundances increased dramatically over $4 \mathrm{~d}$ which these authors suggested were environmental cues in lake water, but not in the microscosms, that triggered prophage induction. Even seemingly nutrient-rich environments can have very different proportions of temperate and lytic viruses, as for example, in feces where the majority of phage are temperate while in sewage the majority of phage are lytic (Lenski 1988). Such studies suggest that the induction rates of temperate phage in nature may be related to as-of-yet undefined environmental cues and should be taken into account in any field studies of virus-induced bacterial mortality.

Finally, all forms of mortality can occur simultaneously in nature. Infected bacteria may still be grazed and die from engulfment rather than lysis. In our series of experiments, the percentage differences in bacterial abundances were generally lower overall in the HMWC enrichments in whole seawater (mean difference of $25 \%$ from its respective control) than in the HMWC enrichments in filtered seawater (mean difference of $70 \%$ from its respective control). Even though one would expect bacterial mortality would be greater in samples with 2 agents of mortality (bacterivores and enriched viruses), we generally observed more rapid declines in those samples with only enriched viruses as a mortality agent. Virus-infected bacteria may have been grazed by bacterivores in those samples with both virus enrichments and the presence of grazers. This factor could lessen the effect of viruses on the bacterial community. An example of this may be found in the study by Bratbak et al. (1990), in which an initial effect of viral mortality on the bacterial community appears to have been followed by the combined effect of protozoan grazing and viral lysis since the total number of viruses significantly decreased within the same time period that heterotrophic flagellates abundances increased.

Bacterial mortality by viral lysis is a significant mode of mortality in marine microbial communities. A field technique for directly detecting bacterial mortality due to the virus size fraction from seawater demonstrates that as little as a 4 -fold enrichment of the virus size fraction from seawater elicited a rapid effect on the bacterial community. Heat lability of the HMWC enrichments, the molecular weight size range of material concentrated from seawater, the presence and increases of $<0.22 \mu \mathrm{m}$ DAPI-fluorescent, DNaseresistant particles, the presence of abundant virus-like particles by electron microscopy, and the mortality effect of the HMWC on the microbial community suggested to us that the effect we observed derived mostly from viruses.

Acknowledgements. The authors thank Drs E. Carter, U.S. Army Corps of Engineers, J. Kremer, Dept Biol. Sci., U.S.C, N. Wheeler, Dept Statis., U.C.L.A., and Ms N. Barbour, Dept Agron., Univ. Georgia, for advice and assistance on statistical analysis. Three anonymous reviewers also greatly improved the text

\section{LITERATURE CITED}

Anderson, I. C., Rhodes, M., Kator, H. I. (1983). Seasonal variations in survival of Escherichia coli exposed in situ in membrane diffusion chambers containing filtered and nonfiltered estuarine water. Appl. environ. Microbiol. 45: $1877-1883$

Belfort, G., Rotem, Y., Katznelson, E. (1976). Virus concentration using hollow fiber membranes - II. Water Res. 10: $279-284$

Berdalet, E., Dortch, Q. (1991). New double-staining technique for RNA and DNA measurement in marine phytoplankton. Mar. Ecol. Prog. Ser. 73: 295-305

Berg, G. (1973). Removal of viruses from sewage, effluents and waters - a review. Bull. WHO 49: 451-460

Berg, G. (1987). Methods of recovering viruses from the environment. CRC Press, Boca Raton

Bergh, Ø., Børsheim, K. Y., Bratbak, G., Heldal, M. (1989) High abundance of viruses found in aquatic environments. Nature 340:467-468

Bitton, G., Mitchell., R. (1974). Effects of colloids on the survival of bacteriophages in seawater. Water Res. 8 $227-229$

Børsheim, K. Y., Bratbak, G., Heldal, M. (1990). Enumeration and biomass estimation of planktonic bacteria and viruses by transmission electron microscopy. Appl. environ. Microbiol. 56: 352-356

Bratbak, G., Heldal, M., Norland, S., Thingstad, T F. (1990). Viruses as partners in spring bloom microbial trophodynamics. Appl. environ. Microbiol. 56: 1400-1405

Carlucci, A. F., Scarpino, P. V., Pramer, D. (1961). An evaluation of factors affecting survival of Escherichia coli in sea water. V. Studies with heat and filter-sterilized sea water. Appl. environ. Microbiol. 9: 400-404

Coleman, A., Maguire, M. K., Coleman, J. R. (1981). Mithramycin and 4'-6-Diamidino-2-phenylindole (DAPI)-DNA staining for fluorescence microspectrophotometric measurement of DNA in nuclei, plastids and virus particles. J. Histochem. Cytochem. 29: 959-968

Crissman, H. A., Darzynkiewicz, Z., Tobey, R. A., Steinkamp. J. A. (1985). Correlated measurements of DNA, RNA, and protein in individual cells by flow cytometry. Science 228 : $1321-1324$ 
DeFlaun, M. F., Paul, J. H., Davis, D. (1986). Simplified method for dissolved DNA determination in aquatic environments. Appl. environ. Microbiol. 52: 654-659

Delbrück, M. (1940). The growth of bacteriophage and lysis of the host. J. gen. Physiol. 23: 643-665

Earnshaw, W. C., King, J., Eiserling, F. A. (1978). The size of the bacteriophage $\mathrm{T} 4$ in solution with comments about the dimensions of virus particles as visualized by electron microscopy. J. molec. Biol. 122: 247-259

Ewert, D. L., Paynter, M. J. B. (1980). Enumeration of bacteriophages and host bacteria in sewage and the activated sludge treatment process. Appl. environ. Microbiol. 39: $576-583$

Fields, K. L. (1969). Comparisons of the actions of colicins $\mathrm{E} 1$ and $\mathrm{K}$ on Escherichia coli with the effect of abortive infection by virulent bacteriophages. J. Bact. 97: 78-82

Ferguson, R. L., Buckley, E. N., Palumbo, A. V. (1984). Response of marine bacterioplankton to differential filtration and confinement. Appl. environ. Microbiol. 47: 49-55

Greaves, M. P., Wilson, M. J. (1969). The adsorption of nucleic acids by montmorillonite. Soil Biol. Biochem. 1: $317-323$

Hara, S., Teruchi, K., Koike, I. (1991). Abundance of viruses in marine waters: assessment by epifluorescence and transmission electron micrascopy. Appl. environ. Microbiol. 57: 2731-2734

Hayes, W. (1976). The genetics of bacteria and their viruses, 2nd edn. John Wiley and Sons, New York

Hobbie, J. E., Daley, R. J., Jasper, S. (1977). Use of Nuclepore filters for counting bacteria by fluorescence microscopy A.ppl. environ. Microbiol. 33: 1225-1228

Kapuscinski, R. B., Mitchell, R. (1980). Processes controlling virus inactivation in coastal waters. Water Res. 14: 363-371

Karl, D. M., Bailiff, M. D. (1989). The measurement and distribution of dissolved nucleic acids in aquatic environments. Limnol. Oceanogr. 34: 543-558

Kornberg, A. (1980). DNA replication. W. R. Freeman, San Francisco

Lee, S., Fuhrman, J. A. (1987). Relationships between biovolume and biomass of naturally derived marine bacterioplankton. Appl. environ. Microbiol. 53: 1298-1303

Lenski, R. E. (1988). Dynamics of interactions between bacteria and virulent bacteriophage. Adv. microb. Ecol. 10: $1-44$

Login, G. R. (1978). Microwave fixation versus formalin fixation of surgical and autopsy tissue. Am. J. med. Technol. 44: $435-437$

Lorenz, M. G., Aardema, B. W., Krumbein, W. E. (1981). Interaction of marine sediment with DNA and DNA availability to nucleases. Mar. Biol. 64: 225-230

Maiti, M. (1978). Mode of action of bacteriophage $\varnothing 149$ on cholera and El Tor Vibrios. Can. J. Microbiol. 24 $1583-1589$

Martinez, J., Garcia-Lara, J., Vives-Rego, J. (1989). Estimation of Esherichia coli mortality in seawater by the decrease in ${ }^{3} \mathrm{H}$-label and electron transport system activity. Microb. Ecol. 17: 219-225

Massey, P. (1970). Antibiotic effects of sea water Process Biochem. 5: 35-36

McCambridge, J., McMeekin, T A. (1980). Relative effects of bacterial and protozoan predators on survival of Esherichia coli in estuarine water samples. Appl. environ. Microbiol. 40: 907-911

Moebus, K. (1972). Seasonal changes in antibacterial activity of North Sea water. Mar. Biol. 13: 1-13

Moebus, K. (1983). Lytic and inhibition responses to bacteriophages among marine bacteria, with special reference to

This article was presented by E. \& B. Sherr, Corvallis,

Oregon, USA the origin of phage-host systems. Helgoländer Meeres unters. 36: $375-391$

Moebus, K. (1987). Ecology of marine bacteriophages. In Goyal, S. M., Gerba, C. P., Bitton, G. (eds.) Phage ecology J. Wiley and Sons, New York, p. 137-156

Mordy, C. W. Carlson, D. J. (1991). An evaluation of fluorescence techniques for measuring DNA and RNA in marine microorganisms. Mar. Ecol. Prog. Ser 73: 283-293

Neter, J., Wassermann, W., Kutner, M. H. (1985). Applied linear statistical models. R. D. Irwin Publ., Homewood

Newell, S. Y., Fallon, R. D., Tabor, P. S. (1986). Direct microscopy of natural assemblages. In: Poindexter, J., Leadbetter, E. R. (eds.) Methods and applications in bacterial ecology. Plenum Press, New York, p. 1-51

Paul, J. H., Jeffrey, W. D., DeFlaun, M. F. (1987). Dynamics of extracellular DNA in the marine environment. Appl environ. Microbiol. 53: 170-179

Porter, K. G., Feig, Y S. (1980). The use of DAPI for identifying and counting aquatic microflora. Limnol. Oceanogr 25: $943-948$

Prescott, B., Li, C. P. (1960). Abalone juice: fractionation of antibacterial spectrum. Proc. Soc. exp. Biol. Med. 105 $498-500$

Primrose, S. B., Day, M. (1977). Rapid concentration of bacteriophage from aquatic habitats. J. appl. Bact. 42 $417-426$

Proctor, L. M., Fuhrman, J. A. (1990). Viral mortality of marine bacteria and cyanobacteria. Nature 343:60-62

Proctor, L. M., Fuhrman, J. A. (1991). The roles of viral infection in organic particle flux. Mar. Ecol. Prog. Ser. 69 $133-142$

Proctor, L. M., Fuhrman, J. A., Ledbetter, M. C. (1988). Marine bacteriophages and bacterial mortality. Eos 69: 1111-1112

SAS Institute Inc. (1988). SAS/STAT ${ }^{\mathrm{TM}}$ user's guide, Release 6.03. SAS Institute Inc., Cary, NC

Sanborn, M. R., Wan, S. K., Bulard, R. (1982). Microwave sterilization of plastic tissue culture flasks for reuse. Appl. environ. Microbiol. 44: 960-964

Saye, D. J., Ogunseitan, O. A., Sayler, G. S., Miller, R. V. (1990). Transduction of linked chromosomal genes between Pseudomonas aeruginosa strains during incubation in situ in a freshwater lake. Appl environ. Microbiol. 56: $140-145$

Saz, A. K., Watson, S., Brown, S. R., Lowery, D. L. (1963). Antimicrobial activity of marine waters. I. Macromolecular nature of antistaphylococcal factor. Limnol. Oceanogr. 8: $63-67$

Servais, P., Billen, G., Vives-Rego, J. (1985). Rate of bacterial mortality in aquatic environments. Appl. environ. Microbiol. 49: $1448-1454$

Sieburth, J. McN., Pratt, D. M. (1962). Anticoliform activity of seawater associated with the termination of Skeletonema costatum blooms. Trans. N.Y. Acad. Sci. 24: 498-501

Shapiro, H. M. (1981). Flow cytometric estimation of DNA and RNA content in intact cells stained with Hoescht 33342 and Pyronin Y. Cytometry 2: 143-150

Snedecor, G. W. Cochran, W. G. (1980). Statistical methods, 7 th edn. Lowa State Univ. Press, Ames

Steel, R. G. D., Torrie, J. H. (1960). Principles and procedures of statistics. McGraw-Hill, New York

Stewart, F. M., Levins, B. R. (1984). The population biology of bacterial viruses: why be temperate? Theor. Popul. Biol. 26: $93-117$

Suttle, C. A., Chan, A. M., Cottrell, M. T. (1990). Infection of phytoplankton by viruses and reduction of primary productivity. Nature 347: 467-469

Manuscript first received: March 1, 1991

Revised version accepted: August 25, 1992 